Article

\title{
Synthesis of a 1,2-Dithienylethene-Containing Donor-Acceptor Polymer via Palladium-Catalyzed Direct Arylation Polymerization (DArP)
}

\author{
Masayuki Wakioka ${ }^{1, *(\mathbb{D},}$, Natsumi Yamashita ${ }^{1}$, Hiroki Mori ${ }^{2}$, Yasushi Nishihara ${ }^{2}$ and \\ Fumiyuki Ozawa ${ }^{1, * \text { (D) }}$ \\ 1 International Research Center for Elements Science (IRCELS), Institute for Chemical Research, \\ Kyoto University, Uji, Kyoto 611-0011, Japan; yamashita.natsumi.22v@st.kyoto-u.ac.jp \\ 2 Research Institute for Interdisciplinary Science, Okayama University, 3-1-1 Tsushimanaka, Kita-ku, \\ Okayama 700-8530, Japan; h-mor@okayama-u.ac.jp (H.M.); ynishiha@okayama-u.ac.jp (Y.N.) \\ * Correspondence: wakioka@scl.kyoto-u.ac.jp (M.W.); ozawa@scl.kyoto-u.ac.jp (F.O.)
}

Received: 10 April 2018; Accepted: 20 April 2018; Published: 23 April 2018

\begin{abstract}
This paper reports the synthesis of D-A polymers containing 1,2-dithienylethene (DTE) units via palladium-catalyzed direct arylation polymerization (DArP). The reaction of dibromoisoindigo (1-Br) and DTE (2-H), in the presence of $\mathrm{Pd}_{2}(\mathrm{dba})_{3} \cdot \mathrm{CHCl}_{3}(0.5 \mathrm{~mol} \%), \mathrm{P}\left(2-\mathrm{MeOC}_{6} \mathrm{H}_{4}\right)_{3}(\mathbf{L 1})(2 \mathrm{~mol} \%)$, pivalic acid (1 equiv) as catalyst precursors, and $\mathrm{Cs}_{2} \mathrm{CO}_{3}$ (3 equiv) as a base affords poly(1-alt-2) with a high molecular weight $\left(M_{\mathrm{n}}\right.$ up to 44,900$)$. Although, it has been known that monomers, with plural $\mathrm{C}-\mathrm{H}$ bonds, tend to form insoluble materials via direct arylation at undesirable $\mathrm{C}-\mathrm{H}$ positions; the reaction of $\mathbf{1 - B r}$ and $\mathbf{2}-\mathbf{H}$ cleanly proceeds without insolubilization. The resulting polymer has a well-controlled structure and exhibits good charge transfer characteristics in an organic field-effect transistor (OFET), compared to the polymer produced by Migita-Kosugi-Stille cross-coupling polymerization. The DArP product displays an ideal linear relationship in the current-voltage curve, whereas the Migita-Kosugi-Stille product shows a $V_{\mathrm{G}}$-dependent change in the charge mobility.
\end{abstract}

Keywords: direct arylation; polycondensation; palladium catalyst; conjugated polymer

\section{Introduction}

$\pi$-Conjugated polymers with donor-acceptor combinations of repeated units (D-A polymers) often exhibit a high device performance in organic field-effect transistors (OFETs) and thin-film solar cells [1-4]. Thus far, such polymers have been prepared by Migita-Kosugi-Stille cross-coupling polymerization. However, this method needs toxic tin reagents for the monomer preparation, and the polymerization forms a highly toxic side product such as $\mathrm{Me}_{3} \mathrm{SnBr}$ [5]. It has also been implicated that the residual impurities that arise from tin reagents may deteriorate the device performance [6-9]. In this context, the palladium-catalyzed direct arylation polymerization (DArP), that proceeds via $\mathrm{C}-\mathrm{H}$ bond activation, has recently emerged as a simple yet fundamental solution for these problems [10-12]. We have developed a highly efficient DArP catalyst using $\mathrm{P}\left(2-\mathrm{MeOC}_{6} \mathrm{H}_{4}\right)_{3}$ (L1) as a ligand to produce D-A polymers with a high molecular weight [13-20]. The resulting polymers have well-controlled structures without tin impurities, thereby leading to good material properties [16].

In this study, we examined the synthesis of a D-A polymer with 1,2-dithienylethene (DTE) as donor units; poly(1-alt-2) in Scheme 1. DTE-based D-A polymers, such as poly(1-alt-2), have been prepared by Migita-Kosugi-Stille cross-coupling polymerization and have proven to be competent compounds in OFETs [21-23]; however, their synthesis via DArP has been poorly successful [24]. This is probably 
due to the existence of plural C-H bonds in DTE. Direct arylation at undesirable C-H positions forms branching and cross-linking polymers, which eventually change to insoluble materials [25-28]. On the other hand, we found that the L1-based catalyst successfully produces the desired poly(1-alt-2) without formation of insoluble materials. The resulting polymer has a well-controlled structure and shows better charge transfer properties in OFET than Migita-Kosugi-Stille cross-coupling products.
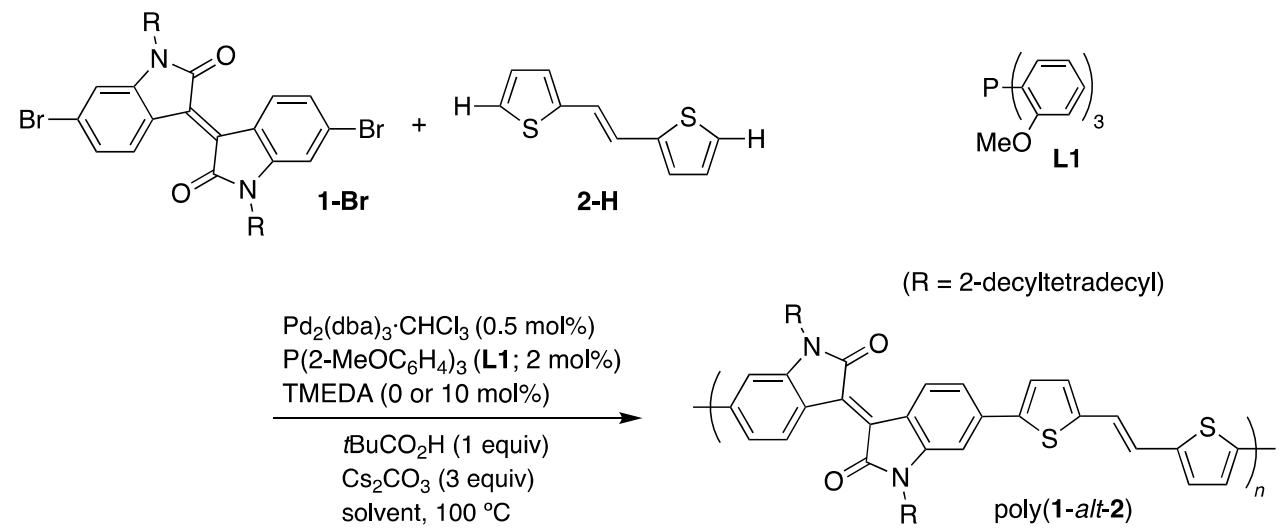

Scheme 1. Synthesis of poly(1-alt-2) via DArP.

\section{Results and Discussion}

\subsection{Synthesis of Poly(1-alt-2)}

First, we examined the DArP of dibromoisoindigo (1-Br) and DTE (2-H) in several types of solvents (Scheme 1). Table 1 summarizes the results. The reaction was conducted with $\mathrm{Pd}_{2}(\mathrm{dba})_{3} \cdot \mathrm{CHCl}_{3}(0.5 \mathrm{~mol} \%), \mathbf{L 1}(2 \mathrm{~mol} \%)$, pivalic acid (1 equiv) as catalyst precursors, and $\mathrm{Cs}_{2} \mathrm{CO}_{3}$ (3 equiv) as a base. When the reaction was carried out in toluene at $100{ }^{\circ} \mathrm{C}$, the reaction mixture turned into a dark red mass in $5 \mathrm{~h}$; however, Soxhlet extraction with $o-\mathrm{Cl}_{2} \mathrm{C}_{6} \mathrm{H}_{4}$ afforded poly(1-alt-2) $\left(M_{n}=17,000\right)$ in almost quantitative yield and no colored substance remained in the extraction thimble (run 1). THF was less effective as a solvent, giving a low-molecular weight polymer $\left(M_{n}=7400\right)$ (run 2). On the other hand, the molecular weight increased in 2-MeTHF $\left(M_{n}=22,700\right)$ (run 3), and when a low-molecular weight portion was removed by Soxhlet extraction with $\mathrm{CHCl}_{3}$, poly(1-alt-2) with $M_{\mathrm{n}}=44,900$ was obtained in a recovery rate of $63 \%$ (run 3a). Unlike the reaction in toluene, the reaction system retained liquidity in 2-MeTHF.

Table 1. DArP of 1-Br and 2-H.

\begin{tabular}{cccccc}
\hline Run $^{\mathbf{1}}$ & Solvent & Time (h) & Yield (\%) $\mathbf{~}^{\mathbf{2}}$ & $\boldsymbol{M}_{\mathbf{n}}{ }^{\mathbf{3}}$ & $\boldsymbol{M}_{\mathbf{w}} \boldsymbol{M}_{\mathbf{n}}{ }^{\mathbf{3}}$ \\
\hline 1 & toluene & 5 & 99 & 17,000 & 2.6 \\
2 & THF & 48 & 80 & 7,400 & 2.0 \\
3 & 2-MeTHF & 24 & $>99$ & 22,700 & 3.9 \\
$3 \mathrm{a}$ & - & - & $(63)^{4}$ & $(44,900)$ & $(2.2)^{4}$ \\
$4^{5}$ & toluene & 24 & 93 & 15,700 & 2.3 \\
$5^{5}$ & 2-MeTHF & 96 & $>99$ & 14,100 & 2.5 \\
\hline
\end{tabular}

${ }^{1}$ Reactions were run at $100{ }^{\circ} \mathrm{C}$ using 1-Br $(0.20 \mathrm{mmol})$ and $2-\mathrm{H}(0.20 \mathrm{mmol}), \mathrm{Pd}_{2}(\mathrm{dba})_{3} \cdot \mathrm{CHCl}_{3}(0.5 \mathrm{~mol} \%)$, L1 $(2 \mathrm{~mol} \%), \mathrm{Cs}_{2} \mathrm{CO}_{3}(0.60 \mathrm{mmol})$, and pivalic acid $(0.20 \mathrm{mmol})$ in toluene $(0.40 \mathrm{~mL})$ unless otherwise stated. ${ }^{2}$ Isolated yield after Soxhlet extraction with hexane, acetone, and $o-\mathrm{Cl}_{2} \mathrm{C}_{6} \mathrm{H}_{4} \cdot{ }^{3}$ Determined by GPC calibration based on polystyrene standards $\left(140{ }^{\circ} \mathrm{C}, o-\mathrm{Cl}_{2} \mathrm{C}_{6} \mathrm{H}_{4}\right) .{ }^{4}$ After removal of a low molecular weight portion from the product in run 3 by Soxhlet extraction with $\mathrm{CHCl}_{3} .{ }^{5}$ The reaction was carried out in the presence of TMEDA (10 $\mathrm{mol} \%)$.

Next, we examined the synthesis of poly(1-alt-2) in the presence of $N, N, N^{\prime}, N^{\prime}$ tetramethylethylenediamine (TMEDA). We have documented that, while the reaction becomes slow, 
the combined use of $\mathbf{L} \mathbf{1}$ and TMEDA effectively prevents the formation of structural defects, including homocoupling, branching, and cross-linking defects leading to insolubilization $[18,19]$. The reaction in toluene proceeded without the formation of a solid mass, and poly(1-alt-2) with $M_{n}=15,700$ was produced in a high yield, in $24 \mathrm{~h}$ (run 4). On the other hand, the DArP in the presence of TMEDA was significantly slow in 2-MeTHF, and the molecular weight remained moderate, even after $96 \mathrm{~h}$ (run 5).

For comparison, poly(1-alt-2) was prepared by Migita-Kosugi-Stille cross-coupling polymerization (Scheme 2). Referring to the literature [22,23], the reactions of $\mathbf{1}-\mathbf{B r}$ and $\mathbf{2}-\mathbf{S n M e}_{3}$ were examined in toluene under two catalytic conditions. The reaction in the presence of $\mathrm{Pd}_{2}(\mathrm{dba})_{3} \cdot \mathrm{CHCl}_{3}$ $(2 \mathrm{~mol} \%)$ and $\mathrm{P}(\mathrm{o} \text {-tolyl })_{3}(8 \mathrm{~mol} \%)$ at $90{ }^{\circ} \mathrm{C}$ for $24 \mathrm{~h}$ yielded poly(1-alt-2) with moderate molecular weight $\left(M_{n}=17,700\right.$, PDI $\left.=1.7\right)$ in quantitative yield [22]. Although the GPC molecular weight of the polymer prepared under those reactions conditions has been reported to be $M_{n}=98,800$ (PDI $=3.1$ ), this value has been estimated at $40{ }^{\circ} \mathrm{C}$, using $\mathrm{CHCl}_{3}$ as the column eluate [22]. In contrast, we performed GPC calibration at $140{ }^{\circ} \mathrm{C}$, using $o-\mathrm{Cl}_{2} \mathrm{C}_{6} \mathrm{H}_{4}$. Thus, we re-examined the polymer under the same GPC conditions using $\mathrm{CHCl}_{3}$ and confirmed that our product $\left(M_{n}=93,400\right.$, PDI $\left.=4.6\right)$ has comparable molecular weight to that of the literature.

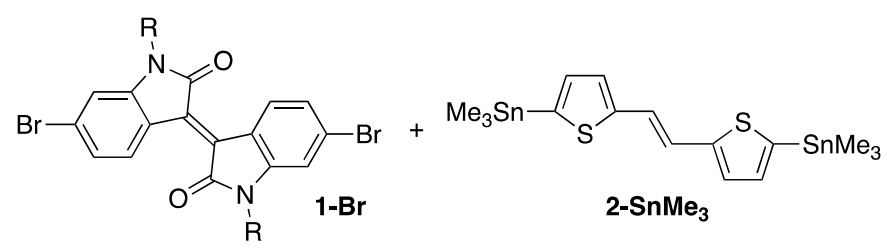

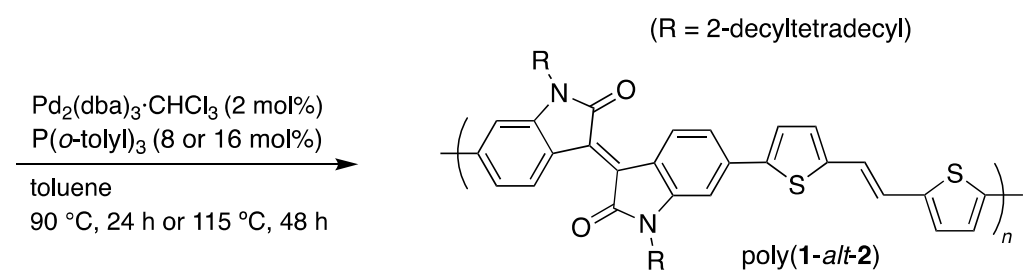

Scheme 2. Synthesis of poly(1-alt-2) via Migita-Kosugi-Stille cross-coupling polymerization.

The synthesis of poly(1-alt-2) via Migita-Kosugi-Stille cross-coupling was also carried out under dilute conditions (monomers: $8 \mathrm{mM})$ using a large amount of $\mathrm{P}(o \text {-tolyl })_{3}(16 \mathrm{~mol} \%)$ at $115{ }^{\circ} \mathrm{C}$ for $48 \mathrm{~h}$ [23]. In this case, the resulting polymer was sparingly soluble and unable to be examined by GPC using $o-\mathrm{Cl}_{2} \mathrm{C}_{6} \mathrm{H}_{4}$ at $140{ }^{\circ} \mathrm{C}$, whereas the molecular weight could be estimated at $150{ }^{\circ} \mathrm{C}$ using 1,2,4- $\mathrm{Cl}_{3} \mathrm{C}_{6} \mathrm{H}_{3}$ as the column eluate $\left(M_{\mathrm{n}}=53,800\right.$, PDI $\left.=2.8\right)$. The NMR analysis described below was performed for a soluble part of the product, prepared by Soxhlet extraction with $\mathrm{CHCl}_{3}(18 \%$ recovery, $M_{\mathrm{n}}=24,400, \mathrm{PDI}=2.5$ ).

\section{2. ${ }^{1} \mathrm{H}$-NMR Analysis of Poly(1-alt-2)}

Figure 1 compares ${ }^{1} \mathrm{H}-\mathrm{NMR}$ spectra of the four types of poly(1-alt-2)s prepared by DArP ( $a$ and $b$ ) and Migita-Kosugi-Stille cross-coupling polymerization ( $\mathrm{c}$ and $\mathrm{d}$ ). The signal assignments are based on the spectra of model compounds of substructures and structural defects (see the Supplementary Material). In Figure 1a-for the polymer of run 4, Table $1\left(M_{n}=15,700\right)$-the spectrum consists of the main signals due to cross-coupling units $\left(\mathbf{A}^{\mathbf{1}}-\mathbf{A}^{\mathbf{6}}\right)$ and small signals arise from three kinds of terminal groups $\left(\mathbf{a}^{\mathbf{1}}-\mathbf{a}^{\mathbf{3}}, \mathbf{b}^{\mathbf{1}}-\mathbf{b}^{\mathbf{4}}\right.$, and $\left.\mathbf{c}^{\mathbf{1}}-\mathbf{c}^{\mathbf{7}}\right)$. Although the signal due to $\mathbf{1 - 1}$ homocoupling defects $(\mathbf{B})$ is observed, its ratio is less than $0.1 \%$. On the other hand, signals assignable to 2-2 homocoupling, branching, and cross-linking defects are not observed. Figure 1b, which corresponds to the polymer of run 3 in Table 1 $\left(M_{n}=22,700\right)$, displays the same signals as Figure 1a, although the relative intensity of each unit is changed, and the signals are broadened reflecting the increase in molecular weight. The number of 1-1 
homocoupling defects $(\mathbf{B})$ is estimated to be less than $0.1 \%$, whereas other structural defects are not observed. Hence, the highly controlled structures of the DArP polymers have been confirmed.
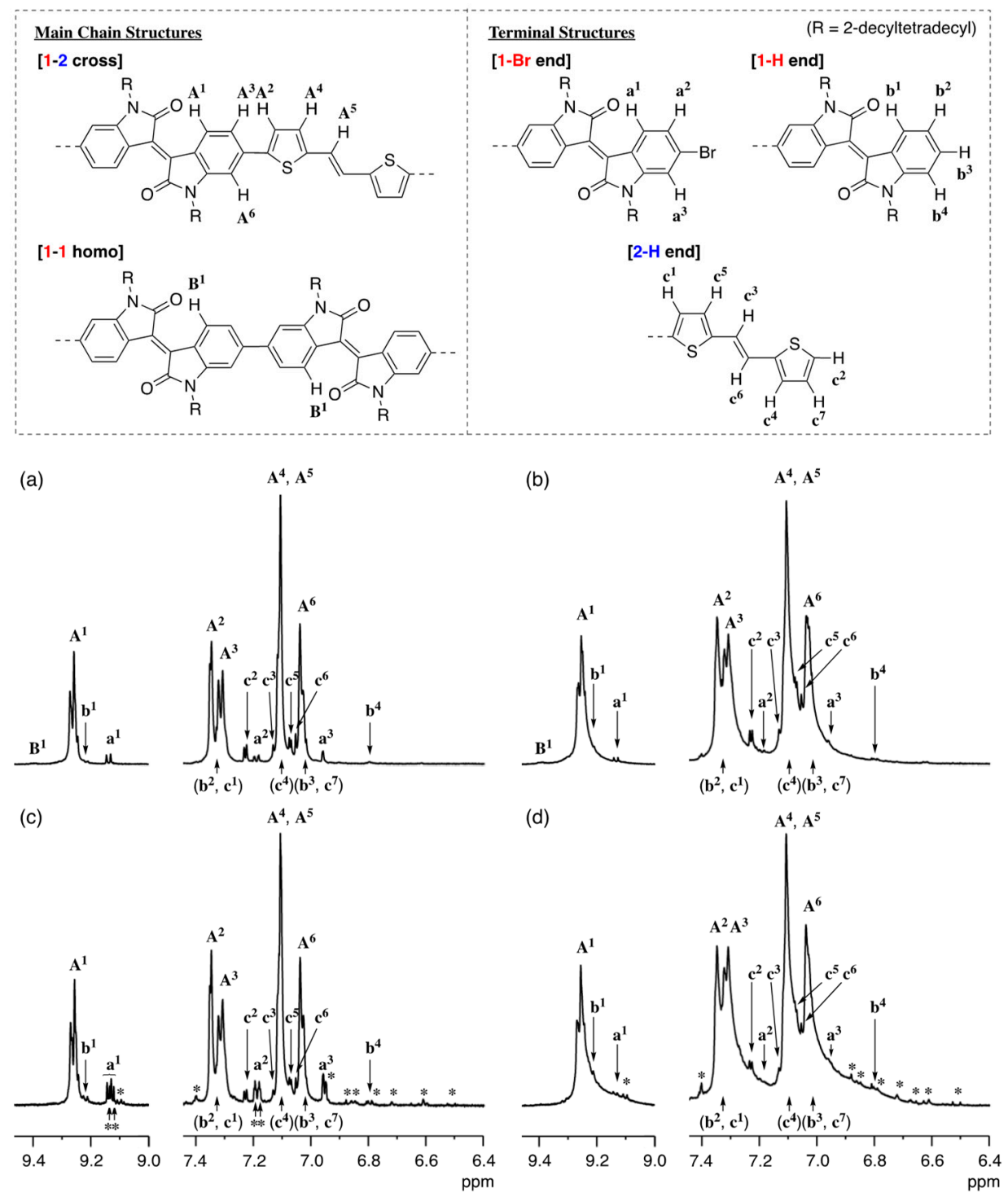

Figure 1. ${ }^{1} \mathrm{H}-\mathrm{NMR}$ spectra of poly(1-alt-2) prepared via $\operatorname{DArP}\left(M_{\mathrm{n}}=15,700(\mathbf{a})\right.$ and $\left.M_{\mathrm{n}}=22,700(\mathbf{b})\right)$ and Migita-Kosugi-Stille cross-coupling polymerization $\left(M_{n}=17,700\right.$ (c) and $M_{n}=24,400($ d) $)$ in $C_{2} D_{2} C l_{4}$ at $130{ }^{\circ} \mathrm{C}(600 \mathrm{MHz}) .{ }^{*}$ : unidentified signals.

On the other hand, Figure 1c,d for the Migita-Kosugi-Stille cross-coupling products $\left(M_{n}=17,700\right.$ and 24,400 ) contain many unidentified peaks in addition to the signals assigned to the core and terminal groups of poly(1-alt-2). Moreover, the signals are somewhat broadened as compared to the DArP products of comparable molecular weight.

\subsection{Electronic Properties of Poly(1-alt-2)}

Table 2 summarizes the optical and electrochemical properties of poly(1-alt-2)s, in thin film, which were evaluated by UV-vis spectroscopy and cyclic voltammetry. The absorption spectra of poly(1-alt-2)s, listed in Table 2, are shown in Figure 2. All spectra consist of two absorption bands around 600-700 (band I) and 650-750 nm (band II). The band I arises from the intramolecular charge transfer (ICT) transitions in the donor-acceptor units, whereas the band II is induced for the aggregation 
of polymer chains through strong intermolecular interactions [29]. In Figure 2, the changes in the relative intensity, from band II to band I, are small. The maximum absorption wavelengths of polymers are approximately the same $\left(\lambda_{\max }=638(3)\right.$ and $\left.700(2) \mathrm{nm}\right)$. Moreover, the absorption onsets $\left(\lambda_{\text {onset }}\right)$ are within the range of 746-753 $\mathrm{nm}$, showing that the optical band gaps are little affected by the polymerization methods, as well as the molecular weight $\left(E_{\mathrm{g}}{ }^{\mathrm{opt}}=1.66(1) \mathrm{eV}\right)$. Indeed, the electronic properties evaluated by cyclic voltammetry are consistent for all polymers: $E_{\mathrm{HOMO}}=-5.34(2) \mathrm{eV}$, $E_{\text {LUMO }}=-3.60(3) \mathrm{eV}, E_{\mathrm{g}}{ }^{\mathrm{CV}}=1.74(2) \mathrm{eV}$.

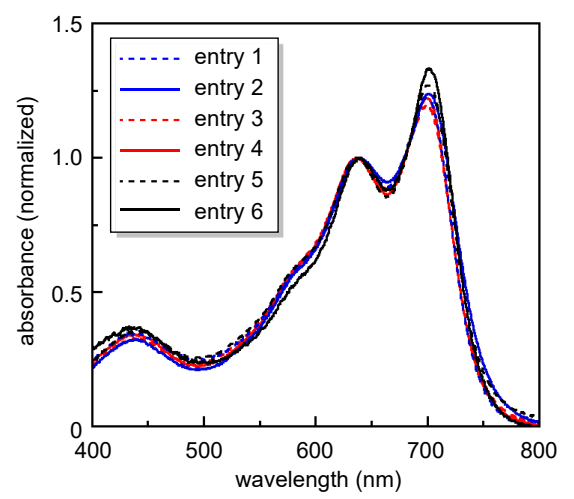

Figure 2. UV-vis spectra of poly(1-alt-2) in thin film. The entry number follows Table 2.

Table 2. Electronic properties of poly(1-alt-2).

\begin{tabular}{cccccccccc}
\hline Entry & Method & $\boldsymbol{M}_{\mathbf{n}}$ (PDI) $^{\mathbf{1}}$ & $\boldsymbol{\lambda}_{\max }{ }^{2}$ & $\lambda_{\text {onset }}{ }^{2}$ & $\boldsymbol{E}_{\mathbf{g}}{ }^{(\mathbf{o p t} / \mathrm{CV}) \mathbf{3}}$ & $\boldsymbol{E}_{\mathbf{\text { ox }}}{ }^{4}$ & $\boldsymbol{E}_{\text {HOMO }}{ }^{5}$ & $\boldsymbol{E}_{\text {red }}{ }^{4}$ & $\boldsymbol{E}_{\text {LUMO }}{ }^{\mathbf{5}}$ \\
\hline 1 & DArP & $15,700(2.3)$ & 637,699 & 747 & $1.66 / 1.73$ & 0.53 & -5.33 & -1.20 & -3.60 \\
2 & DArP & $17,000(2.6)$ & 638,700 & 746 & $1.66 / 1.74$ & 0.54 & -5.34 & -1.20 & -3.60 \\
3 & DArP & $22,700(3.9)$ & 638,700 & 747 & $1.66 / 1.75$ & 0.54 & -5.34 & -1.21 & -3.59 \\
4 & DArP & $44,900(2.2)$ & 639,701 & 753 & $1.65 / 1.74$ & 0.54 & -5.34 & -1.20 & -3.60 \\
5 & Stille & $17,700(1.7)$ & 636,699 & 748 & $1.66 / 1.76$ & 0.54 & -5.34 & -1.22 & -3.58 \\
6 & Stille & $53,800(2.8)$ & 641,702 & 747 & $1.66 / 1.73$ & 0.56 & -5.36 & -1.17 & -3.63 \\
\hline
\end{tabular}

${ }^{1}$ Determined by GPC calibration based on polystyrene standards (entries 1-5: $140{ }^{\circ} \mathrm{C}, o_{-}-\mathrm{Cl}_{2} \mathrm{C}_{6} \mathrm{H}_{4}$; entry $6: 150{ }^{\circ} \mathrm{C}$, $\left.1,2,4-\mathrm{Cl}_{3} \mathrm{C}_{6} \mathrm{H}_{3}\right) .{ }^{2}$ Values in nm; observed by UV-vis spectroscopy in thin films spin-coated on quartz plates. ${ }^{3}$ Values in $\mathrm{eV}$, estimated from the absorption onset $\left(E_{\mathrm{g}}{ }^{\mathrm{opt}}=1240 / \lambda_{\text {onset }}\right)$ and cyclic voltammetry $\left(E_{\mathrm{g}}{ }^{\mathrm{CV}}\right) .{ }^{4}$ Onset potentials in $\mathrm{V}$ (vs. $\left.\mathrm{Fc} / \mathrm{Fc}^{+}\right)$for oxidation $\left(E_{\mathrm{ox}}\right)$ and reduction $\left(E_{\text {red }}\right) .{ }^{5}$ Values in $\mathrm{eV}$, according to the following equation: $E_{\mathrm{HOMO}}=-4.80-E_{\mathrm{Ox}} ; E_{\mathrm{LUMO}}=-4.80-E_{\text {red }}$.

\subsection{OFET Characteristics of Poly(1-alt-2)}

OFET characteristics of the DArP polymers were compared with those of the Migita-Kosugi-Stille cross-coupling products. OFET devices were fabricated on an $n^{+}-\mathrm{Si} / \mathrm{SiO}_{2}$ substrate treated with n-octyltriethoxysilane (OTS) as a self-assembled monolayer (SAM). The active layer of poly(1-alt-2) was formed by spin-coating from a $\mathrm{CHCl}_{3}$ or $\mathrm{o}-\mathrm{Cl}_{2} \mathrm{C}_{6} \mathrm{H}_{4}$ solution, and sequential thermal annealing was carried out at $240{ }^{\circ} \mathrm{C}$ for $30 \mathrm{~min}$ under an inert atmosphere. The solvents for spin-coating were changed according to the solubility of polymers. We confirmed that the solvents little affected the carrier mobility (Table S1).

Poly(1-alt-2) exhibited typical p-type characteristics under ambient conditions in the dark. Table 3 lists the hole mobility observed for the polymers shown in Table 2. The highest hole mobility was observed for the DArP polymer in entry $1\left(M_{n}=15,700, \mu_{h}=0.31 \mathrm{~cm}^{2} \mathrm{~V}^{-1} \mathrm{~s}^{-1}\right)$, and this value was comparable to that for the Migita-Kosugi-Stille cross-coupling product with similar molecular weight in entry $5\left(M_{n}=17,700, \mu_{h}=0.28 \mathrm{~cm}^{2} \mathrm{~V}^{-1} \mathrm{~s}^{-1}\right)$. On the other hand, the hole mobility for the other polymers was low (entries 2-4 and 6). It emerges that the hole mobility depends on the weight average molecular weight $\left(M_{\mathrm{w}}\right)$, not on the number average molecular weight $\left(M_{\mathrm{n}}\right)$. Indeed, the hole mobility decreases significantly with increasing the $M_{\mathrm{w}}$ values. 
To understand the reasons behind the large variation in device performance depending on molecular weight, polymer thin films formed on an OTS-treated substrate were investigated by grazing incidence wide-angle X-ray scattering (GIWAXS) and atomic force microscopy (AFM). These investigations indicated that the hole mobility changes with the surface morphology rather than with the crystallinity (Figures S4-S6). The GIWAXS analysis revealed the predominant edge-on orientation on the substrate for all films. Moreover, in Table 3, the lamellar $d$-spacings $\left(d_{l}\right)$ and $\pi-\pi$ stacking distances $\left(d_{\pi}\right)$ were very similar to each other, regardless of the $M_{\mathrm{w}}$ values and the polymerization methods $d_{l}=21.4(7) \AA$ and $d_{\pi}=3.75(4) \AA$. On the other hand, in the AFM images, the surface morphology clearly changed with $M_{\mathrm{w}}$, and the polymer with a lower $M_{\mathrm{w}}$ value tended to form a smoother surface. The polymers with a high $M_{\mathrm{w}}$ value in entries 4 and 6 showed several clear grain boundaries, suppressing the carrier transport efficiency.

Table 3. OFET characteristics and ordering parameters for poly(1-alt-2).

\begin{tabular}{|c|c|c|c|c|c|c|c|c|}
\hline \multirow[b]{2}{*}{ Entry } & \multirow[b]{2}{*}{ Method } & \multirow[b]{2}{*}{$M_{n}{ }^{1}$} & \multirow[b]{2}{*}{$\mathbf{M}_{\mathrm{w}}{ }^{1}$} & \multicolumn{3}{|c|}{ Transistor Properties } & \multicolumn{2}{|c|}{ Distance $(\AA ̊)^{5}$} \\
\hline & & & & $\mu_{\mathrm{h}}\left(\mathrm{cm}^{2} \mathrm{~V}^{-1} \mathrm{~s}^{-1}\right)^{2}$ & $\mathrm{~V}_{\mathrm{th}}(\mathrm{V})^{3}$ & $\mathrm{I}_{\mathrm{on}} / \mathrm{I}_{\mathrm{off}}{ }^{4}$ & $\mathrm{~d}_{1}{ }^{6}$ & $\mathrm{~d}_{\pi}{ }^{7}$ \\
\hline 1 & DArP & 15,700 & 35,800 & $\begin{array}{c}0.31 \\
(0.21-0.37)\end{array}$ & $\begin{array}{c}-16 \text { to } \\
-5\end{array}$ & $10^{2}-10^{8}$ & 21.1 & 3.76 \\
\hline 2 & DArP & 17,000 & 44,000 & $\begin{array}{c}0.020 \\
(0.013-0.030)\end{array}$ & $\begin{array}{c}-15 \text { to } \\
-5\end{array}$ & $10^{2}-10^{8}$ & 22.0 & 3.76 \\
\hline 3 & DArP & 22,700 & 88,200 & $\begin{array}{c}0.016 \\
(0.012-0.022)\end{array}$ & $\begin{array}{c}-21 \text { to } \\
-2\end{array}$ & $10^{3}-10^{6}$ & 20.7 & 3.74 \\
\hline 4 & DArP & 44,900 & 97,000 & $\begin{array}{c}0.0030 \\
(0.0024-0.0033)\end{array}$ & $\begin{array}{c}-29 \text { to } \\
-4\end{array}$ & $10^{4}-10^{7}$ & 22.0 & 3.74 \\
\hline 5 & Stille & 17,700 & 30,300 & $\begin{array}{c}0.28 \\
(0.15-0.51)\end{array}$ & $\begin{array}{c}-29 \text { to } \\
-3\end{array}$ & $10^{2}-10^{7}$ & 22.0 & 3.79 \\
\hline 6 & Stille & $53,800^{8}$ & $151,000^{8}$ & $\begin{array}{l}0.004 \\
(-)^{9}\end{array}$ & -6 & $>10^{5}$ & 22.0 & 3.72 \\
\hline
\end{tabular}

${ }^{1}$ Determined by GPC calibration based on polystyrene standards $\left(140{ }^{\circ} \mathrm{C}, o_{-}-\mathrm{Cl}_{2} \mathrm{C}_{6} \mathrm{H}_{4}\right)$, unless otherwise stated.

${ }^{2}$ Average mobilities for over 5 devices tested unless otherwise stated. ${ }^{3}$ The threshold voltage. ${ }^{4}$ The on/off current ratio. ${ }^{5}$ Determined by GIWAXS analysis. ${ }^{6} d$-Spacing to the lamellar structure of the edge-on crystallite, $(100)$ along the $q_{\mathrm{z}}$ axis. ${ }^{7} d$-Spacing to the $\pi-\pi$ stacking of the edge-on crystallites, (010) along the $q_{\mathrm{xy}}$ axis. ${ }^{8}$ Determined by GPC calibration and based on polystyrene standards $\left(150{ }^{\circ} \mathrm{C}, 1,2,4-\mathrm{Cl}_{3} \mathrm{C}_{6} \mathrm{H}_{3}\right) .{ }^{9}$ Only one device showed FET characteristics among the 12 devices fabricated.

While the hole mobility was little affected by the polymerization methods, the charge transfer characteristics were clearly different for the DArP and Migita-Kosugi-Stille cross-coupling products. In Figure 3a, the DArP polymer (entry 1, Table 3) has the ideal transfer characteristics, showing a linear correlation in the current-voltage curve. Thus, this polymer exhibited a $V_{\mathrm{G}}$-independent change in the hole mobility. A similar trend was observed for all DArP products (see Figure S2). On the other hand, in Figure 3b, the Migita-Kosugi-Stille cross-coupling product (entry 5, Table 3) exhibited non-ideal double slope characteristics [30], which are often related to the contact resistance and/or the presence of carrier traps due to defects or impurities in the polymer transistors. The same phenomenon has already been documented for the poly(1-alt-2) prepared by Migita-Kosugi-Stille cross-coupling polymerization [22]. 

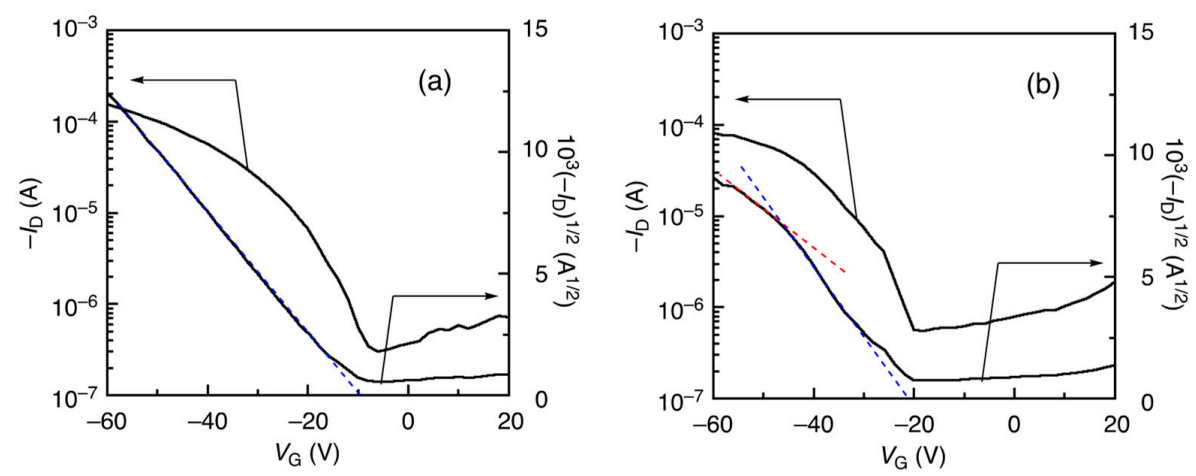

Figure 3. Charge transfer characteristics of the OFETs using poly(1-alt-2) of entries 1 (a) and 5 (b) in Table $3\left(V_{\mathrm{D}}=-60 \mathrm{~V}\right)$.

\section{Conclusions}

We have described the synthesis of D-A polymers containing 1,2-dithienylethene (DTE) units via palladium-catalyzed direct arylation polymerization (DArP). The reaction of dibromoisoindigo (1-Br) and DTE (2-H) using the catalytic system with $\mathrm{P}\left(2-\mathrm{MeOC}_{6} \mathrm{H}_{4}\right)_{3}(\mathbf{L 1})$ as a ligand afforded the desired poly(1-alt-2) with a high molecular weight $\left(M_{n}\right.$ up to 44,900$)$ and yield. The ${ }^{1} \mathrm{H}-\mathrm{NMR}$ analysis revealed a highly controlled structure for the resulting polymer. On the other hand, the ${ }^{1} \mathrm{H}-\mathrm{NHR}$ spectrum of the Migita-Kosugi-Stille cross-coupling polymerization product indicated the contamination of unknown structural defects. These polymers showed almost the same optical properties, independently of the polymerization methods. Moreover, they exhibited comparable charge mobility when the weight average molecular weight $\left(M_{\mathrm{W}}\right)$ was similar. However, the charge transfer characteristics of the DArP product in OFET were superior to those of the Migita-Kosugi-Stille cross-coupling product. The DArP product displayed an ideal linear relationship in the current-voltage curve, whereas the Migita-Kosugi-Stille product showed a non-ideal double-slope curve. The so-called double-slope characteristics have been recognized to be a crucial problem in the practical applications of polymer-based OFETs [30]. Since the physical properties observed by spectroscopic and electrochemical methods were almost the same, the difference in charge transfer characteristics of these products is possibly due to the difference in structural defects. Moreover, there is a possibility that impurities arising from tin reagents cause the deterioration in device performance. Thus, the present study indicates that the highly selective synthesis of $\mathrm{D}$-A polymers via DArP using $\mathrm{P}\left(2-\mathrm{MeOC}_{6} \mathrm{H}_{4}\right)_{3}(\mathbf{L 1})$ as a ligand provides a simple but powerful approach for developing OFETs with good properties.

\section{Materials and Methods}

\subsection{General Considerations}

All manipulations were performed under a nitrogen atmosphere using Schlenk techniques or a glove box. Toluene, THF, and 2-MeTHF were dried over $\mathrm{Na} / \mathrm{Ph}_{2} \mathrm{CO}$, distilled, and stored over activated MS4A. $\mathrm{Cs}_{2} \mathrm{CO}_{3}$ was dried overnight at $120{ }^{\circ} \mathrm{C}$ under vacuum and handled in a glove box. PivOH was distilled and handled in a glove box. TMEDA was dried over $\mathrm{CaH}_{2}$ and distilled. 1-Br [31], 2-H [32], 2-SnMe $\mathbf{M e}_{3}$ [33], and $\mathrm{Pd}_{2}(\mathrm{dba})_{3} \cdot \mathrm{CHCl}_{3}$ [34] were prepared according to the literature. The other chemicals were obtained from commercial sources and used without purification.

\subsection{Direct Arylation Polymerization of $\mathbf{1 - B r}$ and $\mathbf{1 - H}$}

A typical procedure is reported for run 3 in Table 1 . The compounds $\mathrm{Cs}_{2} \mathrm{CO}_{3}(195 \mathrm{mg}, 0.60 \mathrm{mmol})$ and pivalic acid $(20.4 \mathrm{mg}, 0.20 \mathrm{mmol})$ were placed in a $10 \mathrm{~mL}$ Schlenk tube equipped with a Teflon screw cock in a glove box. Then, 1-Br $(219 \mathrm{mg}, 0.20 \mathrm{mmol}), \mathbf{2}-\mathbf{H}(38.5 \mathrm{mg}, 0.20 \mathrm{mmol}), \mathrm{Pd}_{2}(\mathrm{dba})_{3} \cdot \mathrm{CHCl}_{3}$ $(1.0 \mathrm{mg}, 1.0 \mu \mathrm{mol}), \mathbf{L 1}(1.4 \mathrm{mg}, 4.0 \mu \mathrm{mol})$, and 2-MeTHF $(0.4 \mathrm{~mL})$ were added. The mixture was 
stirred at room temperature for $0.5 \mathrm{~h}$, and next at $100{ }^{\circ} \mathrm{C}$ for $24 \mathrm{~h}$. The mixture was cooled up to room temperature, diluted with $\mathrm{CHCl}_{3}(100 \mathrm{~mL})$, and washed with water $(3 \times 10 \mathrm{~mL})$. The organic phase was poured into a vigorously stirred $\mathrm{MeOH}(400 \mathrm{~mL})$. A dark red precipitate was collected by filtration, washed with $\mathrm{MeOH}$, and dried under vacuum overnight. The product was subjected to Soxhlet extraction with acetone and hexane, and next with $o-\mathrm{Cl}_{2} \mathrm{C}_{6} \mathrm{H}_{4}(100 \mathrm{~mL})$ containing diethylammonium diethyldithiocarbamate $(10 \mathrm{mg})$. No colored substance remained in the extraction thimble. The $o-\mathrm{Cl}_{2} \mathrm{C}_{6} \mathrm{H}_{4}$ extract was poured into a vigorously stirred $\mathrm{MeOH}(400 \mathrm{~mL})$, to produce a dark red solid of poly(1-alt-2), in >99\% yield (231 $\left.\mathrm{mg}, M_{\mathrm{n}}=22,700, M_{\mathrm{w}} / M_{\mathrm{n}}=3.9\right)$.

${ }^{1} \mathrm{H}-\mathrm{NMR}\left(\mathrm{C}_{2} \mathrm{D}_{2} \mathrm{Cl}_{4}, 130{ }^{\circ} \mathrm{C}, 600 \mathrm{MHz}\right): \delta 9.26(\mathrm{~d}, J=8.1 \mathrm{~Hz}, 2 \mathrm{H}), 7.35(\mathrm{~d}, J=3.3 \mathrm{~Hz}, 2 \mathrm{H}), 7.32(\mathrm{~d}$, $J=8.5 \mathrm{~Hz}, 2 \mathrm{H}), 7.14-7.08(\mathrm{~m}, 4 \mathrm{H}), 7.04(\mathrm{~s}, 2 \mathrm{H}), 3.77(\mathrm{br}, 4 \mathrm{H}), 2.11-2.01(\mathrm{br}, 2 \mathrm{H}), 1.54-1.22(\mathrm{~m}, 80 \mathrm{H})$, $0.94-0.86(\mathrm{~m}, 12 \mathrm{H})$.

Supplementary Materials: Supplementary materials including detailed experimental procedures, characterizations of all new compounds and polymers, as well as additional figures and tables are available online.

Acknowledgments: This work was supported by KAKENHI (JP17H03055, JP15K17855, JP17K05883) from Japan Society for the Promotion of Science and the ACT-C program of Japan Science and Technology Agency. The GIWAXS experiments were performed on beamline BL46XU of SPring-8 with the approval of the Japan Synchrotron Radiation Research Institute (JASRI) (Proposal 2017B1831). We are grateful to Atsushi Wakamiya (ICR, Kyoto University) for analytical GPC assistance, Takeshi Hasegawa and Takafumi Shimoaka (ICR, Kyoto University) for AFM assistance, and Itaru Osaka (Hiroshima University) and Tomoyuki Koganezawa (JASRI) for the measurement of GIWAXS images. The NMR measurements (600 MHz spectrometer) were supported by the Joint Usage/Research Center (JURC) at ICR, Kyoto University.

Author Contributions: M.W. and F.O. conceived and designed the experiments; M.W., N.Y., and H.M. performed the experiments; M.W., N.Y., and F.O. prepared the manuscript; all authors discussed and commented on the manuscript.

Conflicts of Interest: The authors declare no conflict of interest.

\section{References}

1. Boudreault, P.L.T.; Najari, A.; Leclerc, M. Processable Low-Bandgap Polymers for Photovoltaic Applications. Chem. Mater. 2011, 23, 456-469. [CrossRef]

2. Beaujuge, P.M.; Frechet, J.M.J. Molecular Design and Ordering Effects in $\pi$-Functional Materials for Transistor and Solar Cell Applications. J. Am. Chem. Soc. 2011, 133, 20009-20029. [CrossRef] [PubMed]

3. Zhou, H.; Yang, L.; You, W. Rational Design of High Performance Conjugated Polymers for Organic Solar Cells. Macromolecules 2012, 45, 607-632. [CrossRef]

4. Sirringhaus, H. 25th Anniversary Article: Organic Field-Effect Transistors: The Path Beyond Amorphous Silicon. Adv. Mater. 2014, 26, 1319-1335. [CrossRef] [PubMed]

5. Carsten, B.; He, F.; Son, H.J.; Xu, T.; Yu, L. Stille Polycondensation for Synthesis of Functional Materials. Chem. Rev. 2011, 111, 1493-1528. [CrossRef] [PubMed]

6. Van Mierloo, S.; Hadipour, A.; Spijkman, M.-J.; Van den Brande, N.; Ruttens, B.; Kesters, J.; D’Haen, J.; Van Assche, G.; de Leeuw, D.M.; Aernouts, T.; et al. Improved Photovoltaic Performance of a Semicrystalline Narrow Bandgap Copolymer Based on 4H-Cyclopenta[2,1-b:3,4- $\left.b^{\prime}\right]$ dithiophene Donor and Thiazolo[5,4-d]thiazole Acceptor Units. Chem. Mater. 2012, 24, 587-593. [CrossRef]

7. Nikiforov, M.P.; Lai, B.; Chen, W.; Chen, S.; Schaller, R.D.; Strzalka, J.; Maser, J.; Darling, S.B. Detection and role of trace impurities in high-performance organic solar cells. Energy Environ. Sci. 2013, 6, 1513-1520. [CrossRef]

8. Usluer, O.; Abbas, M.; Wantz, G.; Vignau, L.; Hirsch, L.; Grana, E.; Brochon, C.; Cloutet, E.; Hadziioannou, G. Metal Residues in Semiconducting Polymers: Impact on the Performance of Organic Electronic Devices. ACS Macro Lett. 2014, 3, 1134-1138. [CrossRef]

9. Bannock, J.H.; Treat, N.D.; Chabinyc, M.; Stingelin, N.; Heeney, M.; de Mello, J.C. The influence of polymer purification on the efficiency of poly(3-hexylthiophene): Fullerene organic solar cells. Sci. Rep. 2016, 6, 23651. [CrossRef] [PubMed] 
10. Rudenko, A.E.; Thompson, B.C. Optimization of direct arylation polymerization (DArP) through the identification and control of defects in polymer structure. J. Polym. Sci. Part A Polym. Chem. 2015, 53, 135-147. [CrossRef]

11. Bura, T.; Blaskovits, J.T.; Leclerc, M. Direct (Hetero)arylation Polymerization: Trends and Perspectives. J. Am. Chem. Soc. 2016, 138, 10056-10071. [CrossRef] [PubMed]

12. Pouliot, J.-R.; Grenier, F.; Blaskovits, J.T.; Beaupré, S.; Leclerc, M. Direct (Hetero)arylation Polymerization: Simplicity for Conjugated Polymer Synthesis. Chem. Rev. 2016, 116, 14225-14274. [CrossRef] [PubMed]

13. Wang, Q.; Takita, R.; Kikuzaki, Y.; Ozawa, F. Palladium-Catalyzed Dehydrohalogenative Polycondensation of 2-Bromo-3-hexylthiophene: An Efficient Approach to Head-to-Tail Poly(3-hexylthiophene). J. Am. Chem. Soc. 2010, 132, 11420-11421. [CrossRef] [PubMed]

14. Wakioka, M.; Kitano, Y.; Ozawa, F. A Highly Efficient Catalytic System for Polycondensation of 2,7-Dibromo-9,9-dioctylfluorene and 1,2,4,5-Tetrafluorobenzene via Direct Arylation. Macromolecules 2013, 46, 370-374. [CrossRef]

15. Wakioka, M.; Ichihara, N.; Kitano, Y.; Ozawa, F. A Highly Efficient Catalyst for the Synthesis of Alternating Copolymers with Thieno[3,4-c]pyrrole-4,6-dione Units via Direct Arylation Polymerization. Macromolecules 2014, 47, 626-631. [CrossRef]

16. Wakioka, M.; Ishiki, S.; Ozawa, F. Synthesis of Donor-Acceptor Polymers Containing Thiazolo[5,4-d]thiazole Units via Palladium-Catalyzed Direct Arylation Polymerization. Macromolecules 2015, 48, 8382-8388. [CrossRef]

17. Iizuka, E.; Wakioka, M.; Ozawa, F. Mixed-Ligand Approach to Palladium-Catalyzed Direct Arylation Polymerization: Synthesis of Donor-Acceptor Polymers with Dithienosilole (DTS) and Thienopyrroledione (TPD) Units. Macromolecules 2015, 48, 2989-2993. [CrossRef]

18. Iizuka, E.; Wakioka, M.; Ozawa, F. Mixed-Ligand Approach to Palladium-Catalyzed Direct Arylation Polymerization: Effective Prevention of Structural Defects Using Diamines. Macromolecules 2016, 49, 3310-3317. [CrossRef]

19. Wakioka, M.; Takahashi, R.; Ichihara, N.; Ozawa, F. Mixed-Ligand Approach to Palladium-Catalyzed Direct Arylation Polymerization: Highly Selective Synthesis of $\pi$-Conjugated Polymers with Diketopyrrolopyrrole Units. Macromolecules 2017, 50, 927-934. [CrossRef]

20. Wakioka, M.; Nakamura, Y.; Montgomery, M.; Ozawa, F. Remarkable Ligand Effect of $\mathrm{P}\left(2-\mathrm{MeOC}_{6} \mathrm{H}_{4}\right)_{3}$ on Palladium-Catalyzed Direct Arylation. Organometallics 2015, 34, 198-205. [CrossRef]

21. Zhang, W.; Yu, G. Rational Design of Diarylethylene-Based Polymeric Semiconductors for High-Performance Organic Field-Effect Transistors. J. Polym. Sci. Part A Polym. Chem. 2017, 55, 585-603. [CrossRef]

22. Shin, J.; Um, H.A.; Lee, D.H.; Lee, T.W.; Cho, M.J.; Choi, D.H. High mobility isoindigo-based $\pi$-extended conjugated polymers bearing di(thienyl)ethylene in thin-film transistors. Polym. Chem. 2013, 4, 5688-5695. [CrossRef]

23. Gao, Y.; Deng, Y.; Tian, H.; Zhang, J.; Yan, D.; Geng, Y.; Wang, F. Multifluorination toward High-Mobility Ambipolar and Unipolar n-Type Donor-Acceptor Conjugated Polymers Based on Isoindigo. Adv. Mater. 2017, 29, 1606217. [CrossRef] [PubMed]

24. Gao, Y.; Zhang, X.; Tian, H.; Zhang, J.; Yan, D.; Geng, Y.; Wang, F. High Mobility Ambipolar Diketopyrrolopyrrole-Based Conjugated Polymer Synthesized Via Direct Arylation Polycondensation. Adv. Mater. 2015, 27, 6753-6759. [CrossRef] [PubMed]

25. Lu, W.; Kuwabara, J.; Kanbara, T. Polycondensation of Dibromofluorene Analogues with Tetrafluorobenzene via Direct Arylation. Macromolecules 2011, 44, 1252-1255. [CrossRef]

26. Fujinami, Y.; Kuwabara, J.; Lu, W.; Hayashi, H.; Kanbara, T. Synthesis of Thiophene- and Bithiophene-Based Alternating Copolymers via Pd-Catalyzed Direct C-H Arylation. ACS Macro Lett. 2012, 1, 67-70. [CrossRef]

27. Chang, S.-W.; Waters, H.; Kettle, J.; Kuo, Z.-R.; Li, C.-H.; Yu, C.-Y.; Horie, M. Pd-Catalysed Direct Arylation Polymerisation for Synthesis of Low-Bandgap Conjugated Polymers and Photovoltaic Performance. Macromol. Rapid Commun. 2012, 33, 1927-1932. [CrossRef] [PubMed]

28. Kuwabara, J.; Nohara, Y.; Choi, S.J.; Fujinami, Y.; Lu, W.; Yoshimura, K.; Oguma, J.; Suenobu, K.; Kanbara, T. Direct arylation polycondensation for the synthesis of bithiophene-based alternating copolymers. Polym. Chem. 2013, 4, 947-953. [CrossRef] 
29. Jackson, N.E.; Savoie, B.M.; Kohlstedt, K.L.; de la Cruz, M.O.; Schatz, G.C.; Chen, L.X.; Ratner, M.A. Controlling Conformations of Conjugated Polymers and Small Molecules: The Role of Nonbonding Interactions. J. Am. Chem. Soc. 2013, 135, 10475-10483. [CrossRef] [PubMed]

30. Phan, H.; Ford, M.J.; Lill, A.T.; Wang, M.; Bazan, G.C.; Nguyen, T.-Q. Double-Slope Nonideality in Organic Field-Effect Transistors. Adv. Funct. Mater. 2018, in press. [CrossRef]

31. Grenier, F.; Berrouard, P.; Pouliot, J.-R.; Tseng, H.-R.; Heeger, A.J.; Leclerc, M. Synthesis of new n-type isoindigo copolymers. Polym. Chem. 2013, 4, 1836-1841. [CrossRef]

32. Lee, W.-H.; Kong, H.; Oh, S.-Y.; Shim, H.-K.; Kang, I.-N. Field-effect transistors based on PPV derivatives as a semiconducting layer. J. Polym. Sci. Part A Polym. Chem. 2009, 47, 111-120. [CrossRef]

33. Kim, R.; Amegadze, P.S.K.; Kang, I.; Yung, H.-J.; Noh, Y.-Y.; Kwon, S.-K.; Kim, Y.-H. High-Mobility Air-Stable Naphthalene Diimide-Based Copolymer Containing Extended $\pi$-Conjugation for $n$-Channel Organic Field Effect Transistors. Adv. Funct. Mater. 2013, 23, 5719-5727. [CrossRef]

34. Ukai, T.; Kawazura, H.; Ishii, Y. Chemistry of dibenzylideneacetone-palladium(0) complexes: I. Novel tris(dibenzylideneacetone)dipalladium(solvent) complexes and their reactions with quinones. J. Organomet. Chem. 1974, 65, 253-266. [CrossRef]

(C) 2018 by the authors. Licensee MDPI, Basel, Switzerland. This article is an open access article distributed under the terms and conditions of the Creative Commons Attribution (CC BY) license (http://creativecommons.org/licenses/by/4.0/). 